\title{
Violence against Women in Bangladesh
}

\author{
Nashid Tabassum Khan ${ }^{1}$, Asma Begum², Tayyaba Musarrat Jaha Chowdhury ${ }^{3}$, Bishwajit Kumar Das ${ }^{4}$, \\ Farhana Shahid $^{5}$, Saizuddin Kabir6, Meherunnessa Begum ${ }^{7}$
}

\begin{abstract}
Background: Violence against women has many forms including physical aggression or threats, sexual abuse, emotional abuse, controlling or domineering, intimidation, stalking, passive/covert abuse, and economic deprivations. Alcohol consumption and mental illness can be co-morbid with abuse and present additional challenges when present alongside patterns of abuse. Objective: The objective of this study was to find out the status of victims of Violence against Women along with the causes and consequences of this heinous crime. Materials and method: A retrospective cross sectional study was done in Dhaka Medical College on the victims who underwent treatment at One Stop Crisis Centre (OCC) and burn unit. The victims were interviewed and the data received were later on analyzed by computer and organized in tables. Total cases of Violence against Women were 1143 during the study period. Due permission was taken from the authority. Results: Among the victims about 63\% belonged to 16 to 30 years of age group. Most of the victims (56\%) were from low socioeconomic conditions, $60 \%$ of them were housewife and most of the victims (71\%) were married. Dowry cases and familial conflict (33\% and 32\% respectively) were the main background behind Violence against Women. Conclusion: At community level, improvement of economic status of women as well as women empowerment is essential. Mass awareness about Violence against Women through mass media is needed to be diffused.
\end{abstract}

Keywords: Women; violence; One Stop Crisis Centre (OCC).

Delta Med Col J. Jan 2017;5(1):25 - 29

\section{Introduction}

Domestic violence, also known as abuse, spousal abuse or intimate partner violence, can be broadly defined as a pattern of abusive behaviours by one or both partners in an intimate relationship such as marriage, family, friends or cohabitation. ${ }^{1}$ Domestic violence has many forms including

1. Associate Professor \& Head, Dept. of Forensic Medicine, Z.H. Sikder Women's Medical College, Dhaka, Bangladesh.

2. Associate Professor \& Head, Dept. of Forensic Medicine, Ibn Sina Medical College, Dhaka, Bangladesh.

3. Assistant Professor, Dept. of Forensic Medicine, Holy Family Red Crescent Medical College, Dhaka, Bangladesh.

4. Assistant Professor \& Head, Dept. of Forensic Medicine, Gonoshasthya Samaj Vittik Medical College, Savar, Dhaka, Bangladesh.

5. Assistant Professor, Dept. of Forensic Medicine, Bangladesh Medical College, Dhaka, Bangladesh.

6. Professor, Dept. of Community Medicine, Z.H. Sikder Women's Medical College, Dhaka, Bangladesh.

7. Assistant Professor, Dept. of Community Medicine, Ibn Sina Medical College, Dhaka, Bangladesh.

Correspondence: Dr. Nashid Tabassum Khan. e-mail: khan.nashid23@yahoo.com 
physical aggression (hitting, kicking, biting, shoving, restraining, slapping, throwing objects) or threats, sexual abuse, emotional abuse, controlling or domineering, intimidation, stalking, passive/covert abuse (e.g neglect) and economic deprivation, alcohol consumption and mental illness can be co-morbid with abuse and present additional challenges, when present alongside patterns of abuse. ${ }^{2}$

Awareness, perception and documentation of domestic violence differ from country to country and from area to area. Estimates are that only about third of cases of domestic violence are actually reported in the United States and United Kingdom. ${ }^{3}$ According to the Center for Disease Control (CDC), domestic violence is a serious, preventable public health problem affecting more than 32 million Americans or over $10 \%$ of the U.S population. ${ }^{4}$ Beating wives by husband has been common in all culture perhaps in all times. Bangladesh seems to be no exception. ${ }^{5}$ Newspaper reports in the country clearly indicate that the prevalence of Violence against Women is very high. National data on the general population do not exist. However, small scale studies support the above conviction. ${ }^{6}$ As of now, the estimate of the prevalence of physical Violence against Women by husbands in Bangladesh varies between 30\% and $50 \%$. Despite the seriousness of the problem in terms of violation of human rights and public health consequences, there is a lack of depth of knowledge on the extent, nature and the context of Violence against Women in Bangladesh and other developing countries for various reasons. ${ }^{7}$ of them, methodological difficulties in studying the topic are the important ones. ${ }^{8}$ Interventions to alleviate the problem have mostly been driven towards reducing the harm after the incidence through medical treatments consulting. ${ }^{9}$ More evaluation is needed to assess the effectiveness of violence prevention measure. ${ }^{10}$ To get promising result. it needs increasing education and opportunities for women and girls in their self-esteem and negotiation skills, reducing gender inequalities in communities. ${ }^{11}$

The objective of this study was to find out the status of victims of Violence against Women along with the causes and consequences of this heinous crime.

\section{Materials and method}

This cross sectional study was carried out from July 2013 to June 2014 in total 1143 cases of the victims of Violence against Women, who underwent treatment at One Stop Crisis Centre (OCC) and burn unit of Dhaka Medical College. After obtaining necessary permission and maintaining all the ethical issues, the victims were interviewed. The data received were later on analyzed by computer and organized in tables.

\section{Results}

A total 1143 victims were interviewed. The respondents were very cooperative. Among the subjects, $63.78 \%$ belonged to age group of 16 to 30 years, $19.16 \%$ belonged to age group of 1 to 15 years, $16.27 \%$ belonged to age group of 31 to 45 years and $0.79 \%$ belonged to age group of 46 years or more (Table I).

Regarding marital status of victims, $71.91 \%$ were married and $25.63 \%$ were unmarried, $1.49 \%$ were widow and $0.96 \%$ were divorced (Table II).

Most of the victims $60.37 \%$ were housewife followed by others $(11.46 \%)$, students $(11.11 \%)$ and maid servants (10.85\%) (Table III).

Main reason behind Violence against Women was dowry (32.72\%), familial conflict (32.54\%), sexual assault (19.16\%), extramarital relation $(11.20 \%)$, others $(3.06 \%)$ and domestic violence (1.31\%) (Table IV).

Most of the perpetrators were husband (64.65\%) followed by known person (14.00\%), neighbors 
$(13.30 \%)$, lovers $(3.15 \%)$, house master and mistress $(2.62 \%)$, in - laws and others $(2.27 \%)$ (Table V).

Social status of most of the victim or their family was lower class (Table VI).

Table I: Age distribution of victims $(\mathrm{N}=1143)$

\begin{tabular}{lcc}
\hline Age group (years) & Frequency & Percentage \\
\hline $1-15$ & 219 & 19.16 \\
$16-30$ & 729 & 63.78 \\
$31-45$ & 186 & 16.27 \\
46 \& above & 9 & 0.79 \\
\hline
\end{tabular}

Table II: Marital Status of victims ( $\mathrm{N}=1143)$

\begin{tabular}{lcc}
\hline Marital Status & Frequency & Percentage \\
\hline Married & 822 & 71.91 \\
Unmarried & 293 & 25.63 \\
Widow & 17 & 1.45 \\
Divorce & 11 & 0.96 \\
\hline
\end{tabular}

Table III: Distribution of occupation of victims $(\mathrm{N}=1143)$

\begin{tabular}{lcc}
\hline Occupation & Frequency & Percentage \\
\hline Housewife & 690 & 60.37 \\
Student & 127 & 11.11 \\
Maid Servant & 124 & 10.85 \\
Others & 131 & 11.46 \\
Garments Worker & 71 & 6.21 \\
\hline
\end{tabular}

Table IV: Distribution of violence against women as per cause $(\mathrm{N}=1143)$

\begin{tabular}{lcc}
\hline Causes & Frequency & Percentage \\
\hline Dowry & 374 & 32.72 \\
Familial conflict & 372 & 32.54 \\
Sexual assault & 219 & 19.16 \\
Extra marital relation & 128 & 11.20 \\
Others & 35 & 3.06 \\
Domestic violence & 15 & 1.31 \\
\hline
\end{tabular}

Table V: Distribution of perpetrators of violence against women $(\mathrm{N}=1143)$

\begin{tabular}{lcc}
\hline Perpetrators & Frequency & Percentage \\
\hline Husband & 739 & 64.65 \\
Known person & 160 & 14.00 \\
Neighbor & 152 & 13.30 \\
Lover & 36 & 3.15 \\
Housemaster and mistress & 30 & 2.62 \\
In-Laws and others & 26 & 2.27 \\
\hline
\end{tabular}

Table VI: Distribution of social status of the victims $(\mathrm{N}=1143)$

\begin{tabular}{lcc}
\hline Social class & Frequency & Percentage \\
\hline Lower class & 643 & 56.26 \\
Middle class & 484 & 42.34 \\
Higher class & 16 & 1.40 \\
\hline
\end{tabular}

\section{Discussion}

Bangladesh is one of the least developed countries in the world and its estimated prevalence rate of Violence against Women is extremely high which in turn, is an obstacle to the atonement of equality, development and peace. ${ }^{12}$

Recognizing Violence against Women as a violation of human rights is a significant turning point in the struggle to end Violence against Women globally. ${ }^{13}$ A human rights perspective broadens the definition of Violence against Women and focuses attention on discrimination and inequalities that are maintained or tolerated by the state and that increase women's vulnerability to violence. ${ }^{14}$ Violence against Women has been recognized as a human rights issue since the 1993 World Conference on Human Rights in Vienna, which established that 'Human Rights of women and of the girl-child are an inalienable, integral and indivisible part of universal human rights'. ${ }^{15}$ Violence against Women is the most obvious gender specific violation of human rights and is a form of discrimination against women. ${ }^{16}$ It enforces women's sub ordination and patriarchal structures throughout all levels of society, leading to issues such as the undervaluation of women's economic contributions. Violence against Women is not only embedded in gender norms, gender norms are also constructed through Violence against Women, and the low status of women economically, socially, culturally and politically both constitute and enable the further denial of human rights in gender specific ways often at the hands of family members, male and female. Thus Violence against Women both reflects and 
determines gendered social structures. That is why framing Violence against Women as a human rights violation requiring immediate action is crucial to challenge the economic, social and cultural marginalization of women in Bangladesh. ${ }^{17}$

Domestic violence is undoubtedly a human rights issue and serious deterrent to development. The Vienna Accord of 1994 and the Beijing Declaration and the Platform for Action (1995) have acknowledged this. ${ }^{18}$ The UN has recommended that State parties should act to protect women against violence of any kind especially that occurring within the family. The phenomenon of domestic violence is widely prevalent but has remained largely invisible in the public domain. ${ }^{19}$ Presently, where her husband or his relatives subject a woman to cruelty, it is an offence under section 498-A, IPC. The civil law does not, however, address this phenomenon in its entirety. It is, therefore, needed to enact a law keeping in view the rights guaranteed under articles. $^{20}$

Violence against Women and girls is one of the most widespread violations of human rights. ${ }^{21}$ It can include physical, sexual, psychological and economic abuse, and it cuts across boundaries of age, race, culture, wealth and geography. ${ }^{22}$ It takes place in the home, on the streets, in schools, the workplace, in farm fields, refugee camps, during conflicts and crisis. ${ }^{23}$ It has many manifestations from the most universally prevalent forms of domestic and sexual violence, to harmful practices, abuse during pregnancy, so called honour killings and other types of femicide. ${ }^{24}$

Globally, up to six out of every ten women experience physical and/or sexual violence in their lifetime. A World Health Organization study of 24,000 women in 10 countries found that the prevalence of physical and/or sexual violence by a partner varied from $15 \%$ in urban Japan to $71 \%$ in rural Ethiopia, with most areas being in the
$30-60 \%$ range. From our study, we see that, in Bangladesh, the scenario of domestic violence/domestic abuse/spousal abuse/intimate partner violence is very alarming. ${ }^{25}$ This population study confirms the high levels of domestic violence suggested by earlier works and confirms that it remains a major public health problem in Bangladesh. ${ }^{26}$ Since husbands are the greatest perpetrators of Violence against Women, effective interventions would need to target them. ${ }^{27}$

\section{Conclusion}

The prevailing attitudes that permit and encourage male violence must be directly and creatively addressed. A part of these efforts involves careful research to identify messages and interventions that can change this attitude. In spite of all these initiatives, progress in the achievement of women's rights has been slow world-wide. State should take a fresh commitment to the realization of women's equal rights and should take actions at national level in fulfilling their obligations to women to be systematically monitored and used as a base by women for advocacy. ${ }^{28}$

To combat violence against women:

(1) Removal of remaining reservation on CEDAW Article 2 and 16.1(c) is needed.

(2) The family court governed by Family Law Ordinance 1985 should be led by a 1st class magistrate or Judge whose authority must be same.

(3) Assault and battery within marriage and marital rape should be recognized in the Women and Children Repression Act, 2000.

(4) Training and orientation to law enforcement personnel on Violence against Women human rights and gender to remove negative and disrespectful attitude of police towards women. 


\section{References}

1. Goode WJ. Force and Violence in the Family. J Marriage Fam. 1971;33:624-36.

2. Markowitz S. The Price of Alcohol, Wife Abuse, and Husband Abuse. Southern Econ J. 2000;67(2):279-303.

3. Dutton DG. Patriarchy and Wife Assault: the Ecological Fallacy. Violence and Victims. 1994;9(2):125-40.

4. Tjaden P, Theonmes N. Full Report of the Prevalence, Incidence, and Consequences of Violence against Women: Findings from the National Violence against the Local Survey. Washington, DC: U.S. Department of Justice, Office of Justice Programs, 2000. Publication No. NCJ183781.

5. Kritof ND, WuDunn S. The Women's Crusade. The New York Times, 2009 Aug 17(cited 2014 Aug 20). Available from: http://www. nytimes.com /2009/08 /23/magazine/23/Women-t.html.

6. Dobash RE, Dobash RP. Violence against Wives: A Case against the Patriarchy. 1st ed. New York: Free Press; 1979. p.1-339.

7. Burton B, Duvvury N, Varia N. Justice, Change and Human Rights: International Research and Responses to Domestic Violence. Washington, DC: International Center for Research on Women; 2000. p.1-31.

8. Akanda L, Shamim I. Women and Violence: A Comparative Study of Rural and Urban Violence against Women in Bangladesh. 2nd ed. Dhaka: Women for Women; 1985. p.1-36.

9. Jahan R. Hidden Danger: Women and Family Violence in Bangladesh. Dhaka: Women; 1994.p.1-165.

10. Hartmann B, Boyce JK. A Quiet Violence: View from a Bangladesh village. Dhaka: University Press Ltd.; 1990. p. 1-297.

11. Hadi A. Household Violence against Women in Rural Bangladesh. Dhaka: Research and Evaluation Division, BRAG; 1997. p.3. Watch report: 27.

12. Schuler SR, Hashemi SM, Rilay AP, Akhter S. Credit Programs, Patriarchy and Men's Violence against Women in Rural Bangladesh. Soc Sci Med. 1996;43(12):1729-42.

13. Fischbach RL, Herbert B. Domestic Violence and Mental Health: Correlates and Coundrums within and Across Cultures. Soc Sci Med. 1997;45(8):1161-76.
14. Jejeebhoy SJ. Association between Wife-Beating and Fetal and Infant Death: Impressions from a Survey in Rual India. Stud Fam Plann. 1998;29(3):300-308.

15. OHCHR [Internet].Women's Rights are Human Rights. 2014 (cited 2014 July 12). Available from: http://www. /Documents/Events /WHRD/ Women RightsAreHR.pdf.

16. Sharma S. Tech City's Burning Issue. Hindustan Times, 2007 February 4:8.

17. Krishnan V. Missing Brides of Rajasthan. Hindustan Times, 2007 March 11:15.

18. Sinha K. 37\% Married Women Abused. The Times of India, 2007 March 12.

19. Ratanlal \& Dhirajlal's The Indian Penal Code. 28th ed. New Delhi: Wadhwa \& Company;1997.

20. The UN Committee's Recommendation on Convention on Elimination of All Forms of Discrimination against Women (CEDAW), in its General Recommendation No. XII (1989).

21. The Protection of Women from Domestic Violence Act, 2005 (43 of 2005).

22. Is New Act a Sarkari Okay for Live-Ins? The Times of India, 2006 November 8:2.

23. Centre Considering Bill to Check Domestic Violence: NHRC. The Tribune, 2005 May 11:13.

24. Law Panel Moves on Witness Safety. The Times of India, 2006 September 16:1,9.

25. Bhuyia A, Sharmin T, Hanifi SMA. Nature of Domestic Violence against Women in a Rural Area of Bangladesh: Implication for Preventive Interventions. $\mathrm{J}$ Health Popul Nutr. 2003;21(1):48-54.

26. Farouk SA. Violence against Women: A Statistical Overview, Challenges and Gaps in Data Collection and Methodology and Approaches for Overcoming Them. Geneva: Expert Group Meeting, DAW, ECE and WHO; 2005:20-25.

27. Schuler SRS, Hashemi M, Badal SH. Man's Violence against Women in Bangladesh: Undermined or Exacerbated by Microcredit Programmes? Geneva: Development in Practice, UNICEF; 2000:10-14.

28. Hossain KT. Violence against Women in Bangladesh. 2nd ed. Hon- Kong: Keung Publishing house; 2007. p.40-45. 